\title{
Lipopolysaccharide administration in vivo induces differential expression of CAMP specific Phosphodiesterase 4B mRNA splice variants in the mouse brain
}

\begin{tabular}{|r|l|}
\hline Journal: & Journal of Neuroscience Research \\
\hline Wanuscript ID: & jnr-2011-Feb-4135.R1 \\
\hline Diley - Manuscript type: & Research Article \\
\hline Author: & n/a \\
\hline Complete List of Authors: & $\begin{array}{l}\text { Johansson, Emily; Institut d'Investigacions Biomèdiques de } \\
\text { Barcelona, Consejo Superior de Investigaciones Científicas (IIBB- } \\
\text { CSIC), Department of Neurochemistry and Neuropharmacology } \\
\text { Sanabra, Cristina; Institut d'Investigacions Biomèdiques de } \\
\text { Barcelona, Consejo Superior de Investigaciones Científicas (IIBB- } \\
\text { CSIC), Department of Neurochemistry and Neuropharmacology } \\
\text { Cortés, Roser; Institut d'Investigacions Biomèdiques de Barcelona, } \\
\text { Consejo Superior de Investigaciones Científicas (IIBB-CSIC), } \\
\text { Department of Neurochemistry and Neuropharmacology } \\
\text { Vilaró, Teresa; Institut d'Investigacions Biomèdiques de Barcelona, } \\
\text { Consejo Superior de Investigaciones Científicas (IIBB-CSIC), } \\
\text { Department of Neurochemistry and Neuropharmacology } \\
\text { Mengod, Guadalupe; Institut d'Investigacions Biomèdiques de } \\
\text { Barcelona, Consejo Superior de Investigaciones Científicas (IIBB- } \\
\text { CSIC), Department of Neurochemistry and Neuropharmacology }\end{array}$ \\
\hline Keywords: & $\begin{array}{l}\text { Neuroinflammation, In situ hybridization, COX, TNF-a, } \\
\text { Neuroanatomy }\end{array}$ \\
\hline
\end{tabular}

\section{SCHOLARONE" Manuscripts}


Lipopolysaccharide administration in vivo induces differential expression of cAMP specific Phosphodiesterase 4B mRNA splice variants in the mouse brain

Emily Johansson", Cristina Sanabra", Roser Cortés, M. Teresa Vilaró and Guadalupe Mengod

Departament de Neuroquímica i Neurofarmacologia, Institut d'Investigacions Biomèdiques de Barcelona (CSIC), IDIBAPS, CIBERNED, 08036 Barcelona, Spain.

Corresponding author: Guadalupe Mengod; Department of Neurochemistry and Neuropharmacology, Institut d'Investigacions Biomèdiques de Barcelona, CSICIDIBAPS, Rosselló, 161, 08036 Barcelona, Spain. Phone: +3493-363 8323; Fax: +3493-363 8301; E-mail: guadalupe.mengod@iibb.csic.es

\#: Contributed equally to the study

Running title: LPS-induced PDE4B mRNAs expression in mice brain 


\begin{abstract}
Many inflammatory processes involve cAMP. Pharmacological manipulation of cAMP levels using specific phosphodiesterase (PDE) inhibitors provokes an anti-inflammatory response. The aim of this study was to investigate changes in the pattern and levels of expression of mRNAs coding for the cAMP-specific PDE4 family and subfamilies in mouse brain during the immediate acute immune response provoked by an intraperitoneal injection of lipopolysaccharide (LPS). PDE4B, and furthermore the splice variants PDE4B2 and PDE4B3 were the only mRNAs that showed altered expression. While PDE4B2 presented increased expression at both 3 and $8 \mathrm{~h}$ postinjection, PDE4B3 mRNA showed decreased expression that reached a minimum $8 \mathrm{~h}$ post-injection. PDE4B2 mRNA upregulation was mainly observed in endothelial and macrophage/neutrophil cell populations in the leptomeninges, and the downregulation of PDE4B3 was mainly observed in oligodendrocytes throughout the brain. Our results clearly illustrate the distinctive anatomical distribution and cellular localization of the PDE4Bs during neuroinflammation, and emphasize the importance of PDE4B splicevariant-specific inhibitors as therapeutic tools.
\end{abstract}

Keywords: neuroinflammation, In situ hybridization, COX, TNF- $\alpha$, anatomy

\title{
INTRODUCTION
}

Every day we are exposed to bacteria and viruses that could provoke systemic infection. The negative impact that such infection may have on the central nervous system (CNS) is mediated, among others, by the production of pro-inflammatory cytokines in the periphery, and is normally referred to as sickness behavior (Hart 1988; Konsman et al., 
2002). Neurodegenerative diseases such as Alzheimer's disease and multiple sclerosis can also be exacerbated by systemic infection (Sly et al., 2001; Buljevac et al., 2002). Cyclic adenosine monophosphate (cAMP) plays a significant role as a second messenger in signal-transduction pathways and is regulated by adenylyl cyclases and cyclic nucleotide phosphodiesterases (PDE). Particular attention has been given to the PDE4 isoform owing to the anti-inflammatory effects observed after its inhibition in vitro and in vivo (reviewed by Torphy 1998; Banner \& Trevethick 2004). However, inhibition of the PDE4 family implies the general inhibition of four PDE4 subfamilies, PDE4A, PDE4B, PDE4C and PDE4D, all of which show tissue- and cell-specific distribution (Cherry \& Davis 1999; Pérez-Torres et al., 2000; Miró X et al., 2002; Reyes-Irisarri et al., 2008) as well as intracellular compartmentalization (Houslay \& Adams 2003; Arp et al., 2003). This characteristic provides many opportunities for selective therapeutic targeting (Swinnen et al., 1989; Bender \& Beavo 2006) and the potential to reduce the incidence of secondary effects attributed to PDE4 inhibition (Yamamoto et al., 2006; Boswell-Smith et al., 2006). The emetic side effects observed in clinical trials with PDE4 inhibitors (Hebenstreit et al., 1989) are, for example, related to the expression of PDE4 mRNAs present in the area postrema (Takahashi et al., 1999; Pérez-Torres et al., 2000; Mori et al., 2010). Thus, increased knowledge about the anatomical and cellular localization and involvement of the cAMP-specific PDE4 subfamilies during the acute immune response in the brain may improve their therapeutic potential.

PDE4 represents a family of cAMP-specific PDE consisting of four paralog genes (PDE4A-D), each of which can generate multiple splice variants distinguishable by their unique N-terminal sequences (Houslay \& Adams 2003). More than 20 transcripts have been identified from the four genes (Conti \& Beavo 2007), and these are classified 
as long, short and super-short depending on the presence of regulatory regions called upstream conserved regions (UCR1 and UCR2) that are linked to the catalytic unit (Houslay 1998; Conti 2000). The PDE4B2 isoform is a short variant lacking UCR1, while both PDE4B1 and PDE4B3 are long splice variants (Swinnen et al., 1989; Huston et al., 1997). Evidence suggests that the PDE4B gene is the predominant subtype involved in inflammatory induction by lipopolysaccharide (LPS) in mouse monocytes and macrophages (Jin et al., 2005). Furthermore, upregulation of the expression of the PDE4B mRNA splice variant PDE4B2 in rat brain has been reported in experimental autoimmune encephalomyelitis (EAE), an animal model of multiple sclerosis (ReyesIrisarri et al., 2007).

Previously we briefly reported the effect of LPS in the expression of the mRNA coding for PDE4B splice variants in rat brain (Reyes-Irisarri et al., 2008). The wide use of transgenic mice in the neuroimmunology field prompted us to study, by in situ hybridization, the mRNA expression of several cytokines together with the PDE4 subfamilies in the mouse brain following systemic injection of LPS. To further identify and characterize the cell populations containing the PDE4B mRNA variations, double in situ hybridization studies were performed using several cell markers.

\section{MATERIAL AND METHODS}

\section{Lipopolysaccharide administration}

Six-week-old male C57BL6 mice (15-20 g) were purchased from Charles River Laboratories (France). All experimental procedures followed the European Communities Council Directive of November 24, 1986 (86/609/EEC), and were approved by University of Barcelona and Generalitat de Catalunya ethics committees. Every effort was made to minimize the number of animals used and their suffering. The 
mice were maintained on a 12-h light/dark cycle at a constant environmental temperature with free access to food and water for one week prior to experimentation. A dose-response curve for PDE4B mRNA expression was obtained using the following doses of LPS (serotype 055:B5, Sigma-Aldrich, Steinheim, Germany): 0.1, 0.3, 1, 5, 10 $\mathrm{mg} / \mathrm{kg}(\mathrm{n}=3 /$ dose $)$ dissolved in $0.9 \% \mathrm{NaCl}$. Based on this dose-response curve and in order to obtain unambiguous mRNA expression for double in situ hybridization experiments, $10 \mathrm{mg} / \mathrm{kg}$ bacterial LPS was subsequently administered to the mice by intraperitoneal (i.p.) injection. Animals from two separate experiments were killed by cervical dislocation at $1 \mathrm{~h}$ and $8 \mathrm{~h}(\mathrm{n}=5 /$ time point $), 3 \mathrm{~h}$ and $24 \mathrm{~h}(\mathrm{n}=10 /$ time point $)$ after injection. Controls were included to evaluate the effect of injection with vehicle $(0.9 \% \mathrm{NaCl})$ alone $(\mathrm{n}=5 /$ experiment $)$. In addition, the selected LPS dose was evaluated via a lethality test (Villa \& Ghezzi 2004), in which the animals were monitored until 60 h post-injection $(n=5)$.

\section{Tissue preparation}

Brains were removed immediately after cervical dislocation, rapidly frozen on dry ice and stored at $-20{ }^{\circ} \mathrm{C}$. Coronal tissue sections of whole brain $(14 \mu \mathrm{m}$ thick) were cut on a microtome-cryostat (Microm HM500 OM, Walldorf, Germany), thaw-mounted onto slides coated with 3-aminopropyltriethoxysilane (Sigma-Aldrich), and stored at $-20{ }^{\circ} \mathrm{C}$ until further processing.

\section{Hybridization probes}

The oligonucleotide probes complementary to the mRNAs coding for the different PDE inflammatory and cell markers are shown in Table 1 . The mRNA regions selected for each PDE4B splice variant shared no similarities (Reyes-Irisarri et al., 2008). The hybridization conditions used to detect all mRNAs are described elsewhere (PérezTorres et al., 2000; Miró et al., 2001; Reyes-Irisarri et al., 2005). All oligonucleotides 
were synthesized and then purified by high-performance liquid chromatography (biomers.net GmbH, Ulm, Germany and Isogen Bioscience BV, Maarsden, The Netherlands). The specificity of the autoradiographic signal obtained in the in situ hybridization histochemistry experiments was confirmed by a series of routine controls as previously described (Pompeiano et al., 1992).

Oligonucleotides were labeled at their $3^{\prime}$-end using $\left[\alpha-{ }^{33} \mathrm{P}\right]$ dATP $(3000 \mathrm{Ci} / \mathrm{mmol}$, New England Nuclear, Boston, MA, USA) with recombinant terminal deoxynucleotidyltransferase (TdT) (Roche Diagnostics GmbH, Penzberg, Germany). All vascular cell adhesion molecule-1 (VCAM-1), glial fibrillary acidic protein (GFAP), microtubule-associated protein (MAP-2), myelin basic protein (MBP), and plateletactivating factor receptor (PAFR) oligonucleotides (100 pmol) were individually nonradioactively labeled with TdT (Roche Diagnostics GmbH) and digoxigenin (DIG)-11dUTP (Boehringer Mannheim, Mannheim, Germany) according to a previously described procedure (Schmitz et al., 1991). Labeled probes were purified using ProbeQuant G-50 Microcolumns (GE Healthcare, Buckinghamshire, UK).

\section{In situ hybridization histochemistry}

The protocols for single- and double-label in situ hybridization histochemistry were based on previously described procedures (Tomiyama et al., 1997; Landry et al., 2000) and have been published elsewhere (Serrats et al., 2003; Reyes-Irisarri et al., 2007).

For film autoradiography, hybridized sections were exposed to Biomax-MR (Kodak, Rochester, NY, USA) films for $2-20$ days at $-70{ }^{\circ} \mathrm{C}$ with intensifying screens. Double in situ hybridized sections were treated as described in (Landry et al., 2000). They were then exposed in the dark at $4{ }^{\circ} \mathrm{C}$ for 6 weeks, developed in a Kodak D19 (Kodak) developer for $5 \mathrm{~min}$, and fixed in Ilford Hypam fixer (Ilford).

Analysis of the results 
For single in situ hybridization experiments, semi-quantitative measurements of film optical densities were conducted using an AIS computerized image system (Imaging Research, St Catharines, Ontario Canada). Sections were stained with cresyl-violet to identify brain structures with the aid of the Franklin and Paxinos Mouse Brain Atlas (Franklin \& Paxinos 2007). The optical densities corresponding to the following regions were measured on autoradiograms obtained from coronal tissue sections: Cornu ammonis fields (CA1-2, CA3), dentate gyrus (DG), hippocampal fissure (hf), subfornical organ (SFO), cingulate cortex (Cg), nuclei of the inferior colliculus (IC) and leptomeninges (lepto.).

Statistical comparisons using the factors brain region and treatment were carried out by separate two-way analyses of variance followed by post hoc analysis (Bonferroni's test) for treatment and time for each brain region. All statistical analyses were performed using GraphPad Prism 4 (GraphPad Software, San Diego, CA).

For double in situ hybridization experiments, tissue sections were examined in an Olympus BX51 Stereo Microscope (Olympus, Tokyo, Japan) equipped with bright- and dark-field condensers for transmitted light. Hematoxylin \& eosin staining was used to determine whether the PAFR-positive cells in the parenchyma corresponded to infiltrating neutrophils. VCAM-1-, PAFR-, GFAP-, MBP- and MAP-2-positive cells exhibited a dark precipitate (alkaline phosphatase reaction product) surrounding or covering the nucleus. PDE4B2 and PDE4B3 mRNA hybridization signals were considered positive when the accumulation of silver grains over the stained cellular profiles was visually estimated to be four times greater than that of the background. Quantification was performed by recording the percentage of DIG-positive cells also expressing PDE4B2 or PDE4B3 mRNA. Cells were counted using the Visiopharm 
Integrator System (Visiopharm Software, Hørsholm, Denmark) for stereological analysis.

\section{TUNEL and Fluoro-Jade B staining}

DNA fragmentation was histologically examined using the in situ Apoptosis Detection System Fluorescein (Promega, Madison, WI, USA). Sections were stained according to the manufacturer's recommendations. Sections were mounted using VECTASHIELD ${ }^{\circledR}$ + DAPI (Vector Laboratories, Burlingame, CA, USA) to stain the nuclei.

For Fluoro-Jade staining sections were fixed in $4 \%$ paraformaldehyde in PBS for 20 min and rinsed in distilled water three times for $5 \mathrm{~min}$. They were then immersed in $80 \%$ ethanol/1\% sodium hydroxide for $5 \mathrm{~min}$, followed by $70 \%$ ethanol and distilled water for $2 \mathrm{~min}$ each. The slides were then transferred to a solution of $0.06 \%$ potassium permanganate for 10 min to block background staining. After an additional water rinse, the sections were stained for $20 \mathrm{~min}$ in $0.0004 \%$ Fluoro-Jade B (Millipore, Temecula, CA, USA) and $0.1 \%$ acetic acid. The slides were then rinsed in water, dried, soaked in xylene, and mounted with Entellan.

\section{Lectin staining and immunohistochemistry}

For detection of T-cells a polyclonal rabbit antibody was used to stain anti-human CD3 (Dako Cytomation, Glostrup, Denmark, \# A 0452) prepared against a synthetic peptide comprising amino acids 156-168 from the cytoplasmic part of the human CD3e-chain coupled to thyroglobulin. Lycopersicon esculentum (Tomato) lectin (Vector Laboratories) was used to stain microglial cells. In brief, sections were fixed at $4{ }^{\circ} \mathrm{C}$ in $4 \%$ paraformaldehyde and then incubated in $1 \% \mathrm{H}_{2} \mathrm{O}_{2}$ (Sigma-Aldrich) in $1 \mathrm{X}$ PBS. Preincubation and incubation with anti-human CD3 and biotinylated goat anti-rabbit antibody (Vector Laboratories) or lectin and ExtrAvidin-peroxidase (Sigma-Aldrich) were carried out in a 1x PBS solution containing 2\% normal goat serum (Vector 
Laboratories). The primary antibody, anti-human CD3, was incubated for $1 \mathrm{~h}$ at $37{ }^{\circ} \mathrm{C}$ and lectin was incubated overnight at $4{ }^{\circ} \mathrm{C}$, followed by incubation with biotinylated secondary antibody or ExtrAvidin-peroxidase respectively, and subsequent incubation in $\mathrm{ABC}$ solution (Vectastain Elite $\mathrm{ABC}$ Kit; Vector Laboratories) according to the manufacturer's instructions. The color reaction was performed using diaminobenzidine tetra hydrochloride (DAB) solution $(0.05 \mathrm{M}$ Tris- $\mathrm{HCl} \mathrm{pH} 7.0,0.3 \mathrm{mg} / \mathrm{ml} \mathrm{DAB}$ (SigmaAldrich), $10 \mu \mathrm{l} / \mathrm{ml}$ dimethyl sulfoxide (Sigma-Aldrich), $0.64 \mathrm{mg} / \mathrm{ml} \mathrm{NaN}$ (Merck, Darmstadt, Germany) and $0.06 \mu \mathrm{l} / \mathrm{ml} \mathrm{H}_{2} \mathrm{O}_{2}$ (Sigma-Aldrich) at room temperature for 5 minutes each. The sections were mounted in Mowiol (Calbiochem).

\section{Preparation of the figures}

Images from film autoradiograms were obtained using a Wild 420 macroscope (Leica Microsystems, Wetzlar, Germany) equipped with a digital camera (DXM1200 F, Nikon, Tokyo, Japan) and ACT-1 Nikon software. Microphotography was performed with an Olympus BX51 Stereo Microscope (Olympus) equipped with a digital camera (DP71, Olympus). Figures were assembled using Adobe Photoshop (Adobe Systems, San Jose, CA, USA); only contrast and brightness were adjusted to optimize the images. Figures illustrating double in situ hybridization and magnification of lectin staining consist of high-magnification images taken in multiple (3-4) focal planes, merged using Cell^P analysis software (Olympus).

\section{RESULTS}

No severe effects on cell survival were observed $24 \mathrm{~h}$ after LPS administration. A number of necrotic cells were detected in the dentate gyrus of the hippocampus when tissue sections were stained with Fluoro-Jade B (Fig. 1A). Deoxynucleotidyl transferase-mediated dUTP-nick end labeling (TUNEL) experiments also revealed a 
few apoptotic cells in the same brain area (Fig. 1B). No other brain region investigated showed positive staining for either Fluoro-Jade B or TUNEL $24 \mathrm{~h}$ after injection (data not shown). The lethality test showed that the LPS dose provoked septic shock in animals at a later time point based on a mortality rate of approximately $80 \%, 60 \mathrm{~h}$ after LPS injection.

\section{Expression of inflammatory markers following LPS administration}

To validate our animal model of acute immediate neuroinflammation we first analyzed the response of four typical inflammatory markers. Visual analysis of images from film autoradiograms obtained after in situ hybridization histochemistry showed a timedependent response. For cyclooxygenase-2 (COX-2), interleukin-1 $\beta$ (IL-1 $\beta$ ), tumor necrosis factor- $\alpha$ (TNF- $\alpha)$ and VCAM-1 mRNA, the initial increase in expression was observed $1 \mathrm{~h}$ after administration, followed by a peak at $3 \mathrm{~h}$ (Fig. 2A-H), and a subsequent decline after 8 and 24 h (data not shown). The highest level of hybridization for GFAP mRNA was visible at $24 \mathrm{~h}$ (Fig. $2 \mathrm{H})$.

Microglial activation was observed in the circumventricular organs (CVOs) and brain regions proximal to the leptomeninges in response to LPS administration (Fig. 3), and morphological changes were identified $3 \mathrm{~h}$ and $8 \mathrm{~h}$ post-injection (Fig. 3B, C). No infiltrating lymphocytes $\left(\mathrm{CD}^{+}\right)$were observed in any of the brain regions analyzed (data not shown).

\section{Expression of cAMP-specific PDE mRNAs following LPS administration}

We first identified the basal mRNA expression of the PDE4B family (data not shown) and the four PDE4B splice variants (Fig. 4) in the mouse brain. Following systemic LPS injection the relative optical densities showed no changes in mRNA expression for PDE4A, PDE4D or the PDE4B splice variants PDE4B1 or PDE4B4 (data not shown). We then focused on the anatomical location of the mRNA alterations observed for 
PDE4B and the splice variants PDE4B2 and PDE4B3 following LPS administration (Fig. 5 and 6). Alterations in the mRNA expression of PDE4B2 were detected even following a low dose of LPS $(0.3 \mathrm{mg} / \mathrm{kg}$ ) (data not shown); however, the enhanced effect on mRNA expression obtained with the higher dose used here facilitated the anatomical description and analysis of our results.

\section{Leptomeninges}

The leptomeninges are in close contact with the exterior of the brain, and thus may show an early reaction to acute immediate inflammation. Under basal conditions, none of the PDE4B mRNAs investigated were expressed in the leptomeninges (Fig. 4M-P). The observed upregulation of PDE4B mRNA expression (Fig. 5A,D,G) was reflected in the increased intensity of PDE4B2 mRNA expression as early as $1 \mathrm{~h}$ after LPS administration, followed by a peak at $3 \mathrm{~h}$ (Fig. 5E, 6A) and a marked return towards basal levels $24 \mathrm{~h}$ post-injection (Fig. 6A). Interestingly, there was a slight trend towards a reduction in PDE4B3 mRNA expression after $8 \mathrm{~h}$ (Fig. 5I and 6B), followed by recovery at $24 \mathrm{~h}$ (Fig. 6B) in this area.

An increase in both VCAM mRNA-positive cells (endothelial cells) and PAFR mRNApositive cells (macrophages/neutrophils) was observed in the leptomeninges in response to peripheral inflammation. Double in situ hybridization was used to investigate whether the augmented PDE4B2 mRNA expression was associated with the increase in inflammatory cell populations. There was notable upregulation of the expression $(61 \%$ and 56\%, 3 and $8 \mathrm{~h}$ following LPS injection respectively) of PDE4B2 mRNA in the VCAM mRNA-positive cells (endothelial cells) (Fig. 7A) following their appearance after LPS administration. Likewise, the PAFR-positive cell population expressed this mRNA at a similar level (around 50\%) (Fig. 7B), regardless of the time since LPS injection (Table 2). 


\section{Inferior colliculus}

This area consists of the external cortex and the nucleus of the brachium of the inferior colliculi (IC). The IC was used here as an example of the parenchyma proximal to areas in close contact with the exterior of the brain. Under basal conditions the expression of PDE4B splice variant mRNAs in this area was moderate to low except for PDE4B3, which showed higher levels of hybridization (Fig. 4M-P).

Dark patches observed $3 \mathrm{~h}$ after injection demonstrated that the mRNA expression of PDE4B2 was upregulated in and around microvessels in the IC (Fig. 5E); $8 \mathrm{~h}$ postinjection a clear increase was observed in this entire area (Fig. 5H and Fig. 6A). Semiquantitative analysis revealed significant downregulation of PDE4B3 mRNA expression $8 \mathrm{~h}$ post-injection, followed by a return to basal levels at $24 \mathrm{~h}$ (Fig. 6B).

In this brain area PAFR-mRNA-positive cells and astrocytes (GFAP-mRNA-positive) showed the highest percentage of co-expression with PDE4B2 mRNA after $3 \mathrm{~h}$, whereas all three cell populations (microglia/macrophages, astrocytes and activated endothelial cells) investigated expressed around 35\% of PDE4B2 mRNA $8 \mathrm{~h}$ after LPS administration (Table 2). The PAFR-positive cells in this area likely represent microglia and infiltrating macrophages and not neutrophils, since no recruitment/infiltration of these was observed with hematoxylin and eosin staining (data not shown).

With regards PDE4B3 mRNA, oligodendrocytes positive for the mRNA coding for MBP expressed this splice variant abundantly (around 70-80\%) (Fig. 8A), with reduced co-expression observed following LPS injection. A relatively constant percentage of neurons (MAP-2-positive cells) were positive for PDE4B3 mRNA in this region (Fig. 8B), with no distinction between time points following LPS-injection or in the control (Table 2). The number of cells counted was similar in control and LPSinjected animals. 


\section{Subfornical organ and hippocampal formations}

We chose the SFO as an example of one of the CVOs, a brain region lacking a bloodbrain barrier, whereas the hippocampal formations were investigated due to their high density of microvessels. Significant alterations in PDE4B2 and PDE4B3 mRNA expression were seen in the SFO (Fig. 6). In the hippocampus there was a trend for increased PDE4B2 mRNA expression as early as $1 \mathrm{~h}$ after LPS administration, with a sustained increase at all time points after administration (Fig. 6A). On the contrary, for PDE4B3 mRNA, an overall trend for downregulation was observed, beginning $1 \mathrm{~h}$ postinjection (Fig. 6B).

\section{Cingulate cortex}

The Cg (anterior) also represents part of the parenchyma proximal to areas in close contact with the brain exterior. In control animals, PDE4B2 and PDE4B4 mRNA showed high levels of hybridization in the external granule cell layer whereas uniform expression was observed in other $\mathrm{Cg}$ areas (Fig. $4 \mathrm{~F}$ and $\mathrm{H}$ ). The mRNA expression of the PDE4B1 and PDE4B3 splice variants was similar in the cortical layers even though PDE4B1 showed a somewhat marbled hybridization pattern (Fig. 4E and 4G). PDE4B3 mRNA was readily expressed in oligodendrocytes (around 70\%) in control animals (Table 2), and reduced co-expression was observed after LPS administration at both time points investigated (data not shown), similar to that observed in the IC. The neuronal cell population expressed PDE4B3 mRNA moderately (around 40\%) in the $\mathrm{Cg}$ of both treated and untreated animals (Table 2). The number of cells counted was similar in control and LPS-injected animals.

\section{DISCUSSION}


Activation of the immune response following systemic infection often results in neuroinflammation and consequently in negative effects on the CNS (Park \& Shin 1996; Villa \& Ghezzi 2004; Semmler et al., 2005). The objective of our study was to analyze the effect of acute immediate neuroinflammation on PDE4 mRNA transcription in the brain. The importance of these enzymes in regulating cAMP levels during the inflammatory process in the peripheral nervous system is well established (Jin \& Conti 2002; Jin et al., 2005; Reyes-Irisarri et al., 2007; Reyes-Irisarri et al., 2008). Our results provide evidence of their importance in the central nervous system.

We found that the PDE4B subfamily and the two splice variants PDE4B2 and PDE4B3 were the only cAMP-specific PDE4s that showed altered mRNA expression in mouse brain in response to neuroinflammation. The increase in hybridization levels of the PDE4B2 isoform complements previous results for rat brain (Reyes-Irisarri et al., 2008). However, to our knowledge, the decrease in mRNA expression of the PDE4B3 splice variant observed here has not been described previously. Additionally, our results show that PDE4B2 mRNA upregulation was observed in all inflammatory cell populations investigated, namely microglia/macrophages, astrocytes and activated endothelial cells, with a time-dependent effect. Given the generally high expression of PDE4B3 mRNA under basal conditions throughout the brain we postulated that the observed reduction would probably be detected in cell populations present in the healthy brain. In accordance with this, oligodendrocytes abundantly expressed PDE4B3 mRNA with reduced levels of expression observed following acute neuroinflammation. We should point out that the high dose of LPS used provokes experimental septic shock at later time points, leading to apoptosis in the rodent brain (Khan et al., 2002; Semmler et al., 2005), and that this is important when considering the pharmacological applications of this study. However, the fact that even a low LPS dose provokes 
alterations in the mRNA expression of PDE4B splice variants illustrates the relevance of this work.

\section{Involvement of PDE4B2 mRNA during acute inflammation in mouse brain}

Our results, together with other reports (Graeber \& Streit 1990; Breder et al., 1994; Breder \& Saper 1996; Elmquist et al., 1997; Quan et al., 1998a; Quan et al., 1998b; Laflamme et al., 1999; Schiltz \& Sawchenko 2002), suggest the basic involvement of leptomeningeal cells during the initial-phase response of acute neuroinflammation, followed by activation of the immune response in brain areas in close proximity, leading to an extended cellular response throughout the brain. The upregulation observed in brain areas proximate to the leptomeninges and other areas of the parenchyma in close contact with the CVOs might partly be explained by cross-talk between the periphery and the CNS (reviewed in Johnson \& Gross 1993). Furthermore, direct uptake of LPS through the BBB-endothelium has been suggested in mice after high peripheral LPS doses, although the exchange rate was much lower in whole brain compared to BBB-deficient areas (Kloss et al., 2001).

COX-2 and IL-1 $\beta$ hybridization patterns showed a clear initial-phase increase in mRNA expression, further confirming neuroinflammation (Elmquist et al., 1997; Quan et al., 1998b; Schiltz \& Sawchenko 2002), and this response was reflected in the patterns observed here for PDE4B2 mRNA upregulation. In rat brain, COX-2 is principally induced in perivascular cells and moderately induced in endothelial cells following LPS administration (Elmquist et al., 1997; Schiltz \& Sawchenko 2002). Our results showed that the initial PDE4B2 mRNA upregulation was mainly located in endothelial and macrophage/microglia cell populations in the leptomeninges. The patchy pattern observed around microvessels further suggests a perivascular location of the upregulated mRNA. However, no expression of COX-2 was reported in CVOs after 
inflammatory induction (Quan et al., 1998a), although such brain areas show a strong increase in PDE4B2 mRNA following LPS administration. COX-2 transcription is induced by IL-1 $\beta$ (Laflamme et al., 1999) and has rate-limiting effects on prostaglandin E2 $\left(\mathrm{PGE}_{2}\right)$ production (reviewed in Goppelt-Struebe 1995). Furthermore, the augmenting effect that $\mathrm{PGE}_{2}$ has on intracellular cAMP levels has been shown to have a direct impact on PDE4B2 mRNA expression in cell cultures (Oger et al., 2002), suggesting that COX-2 might be an important transcriptional regulator for PDE4B2 mRNA during the acute immediate immune response in the CNS. However, no modification of PDE4B2 mRNA expression following LPS administration was observed in preliminary results from our laboratory when the mice were treated with a well-known COX inhibitor, Indomethacin. Altogether these data suggest that $\mathrm{PGE}_{2}$ is not critical for activation of the cAMP cascade and subsequent induction of PDE4B2 mRNA transcription (D'Sa et al., 2002) in this model of acute neuroinflammation.

PDE4B2 mRNA expression in the parenchyma, which we report here, is comparable to the reported upregulation of the proinflammatory cytokine TNF- $\alpha$ observed in neuronal cell groups adjacent to CVOs during the late phase of the cerebral response to LPS (Breder et al., 1994). The importance of the PDE4B2 splicing form in the induction of TNF- $\alpha$ secretion by circulating leukocytes following LPS administration has been demonstrated previously (Jin \& Conti 2002). TNF- $\alpha$ is mainly released by macrophages and leukocytes in the periphery and by microglia and infiltrating leukocytes and macrophages in the CNS (Elmquist et al., 1997; Jin et al., 2005; Lambertsen et al., 2009). Even though no cellular infiltration (lymphocytes and neutrophils) was detected after LPS administration, upregulation of PDE4B2 mRNA expression was observed $8 \mathrm{~h}$ post-injection in the parenchyma, suggesting that microglia/macrophages could be involved. Furthermore, activated astrocytes are also known to release TNF- $\alpha$, although 
at much lower levels than microglia (Liberto et al., 2004). We observed upregulation of GFAP mRNA $8 \mathrm{~h}$ post-injection, with expression continuing to increase after $24 \mathrm{~h}$, and we also showed that both activated astrocytes and microglia were positive for PDE4B2 mRNA in the parenchyma. Taken together, these data suggest that PDE4B2 could play an important role in TNF- $\alpha$ secretion in the brain, as in the periphery.

Further biochemical analyses in cell cultures would form an interesting step towards understanding the induction of PDE4B2 mRNA transcription by inflammatory components.

\section{Involvement of PDE4B3 during acute inflammation in mouse brain}

Our results, together with previous reports of the constitutive expression of PDE4B3 mRNA in primary cerebral cortical neuronal cultures (D'Sa et al., 2002) and its reported expression during memory consolidation (Ahmed \& Frey 2003) imply a more neuronal role for this PDE4B splice variant than that observed for PDE4B2. However, the reduced PDE4B3 mRNA levels observed during acute neuroinflammation suggest involvement of PDE4B3 in the immunological reaction.

Decreased PDE4B3 mRNA expression was reflected in the lower percentage of colocalization with the oligodendrocyte population in the $\mathrm{Cg}$ and IC after LPS administration. The release of TNF- $\alpha$ and IL-1 $\beta$ from astrocytes and microglia can induce oligodendrocyte death (D'Souza et al., 1996; Cai et al., 2003), suggesting that a decrease in oligodendrocytes might provoke the downregulation of PDE4B3 expression. However, total cell counts were similar at all time points and were comparable to control animals, indicating that the decreased mRNA expression in oligodendrocytes is related to a lower transcription level. Given the proven anti-inflammatory effect of PDE4B inhibition (reviewed in Banner \& Trevethick 2004), it seems reasonable to 
suggest that the natural downregulation of PDE4B3 might have neuroprotective consequences.

In summary, we show that the mRNA expression of the PDE4B splice variants PDE4B2 and PDE4B3 is clearly and differentially altered in mouse brain following peripheral inflammation. The results obtained here substantiate the possibility of more precise pharmacological regulation at a cellular level via splice-variant-specific inhibition.

\section{Acknowledgements}

This work was supported by grants awarded by the Spanish Ministerio de Educación y Ciencia and FEDER Funds (SAF2006-10243; SAF2009-11052). Emily Johansson was a recipient of a fellowship from the Ministerio de Educación y Ciencia and Cristina Sanabra was a recipient of a fellowship from the IDIBAPS. We thank Rocío Martín for technical assistance and Robyn Rycroft for English corrections.

\section{REFERENCES}

Ahmed, T., Frey, J.U., 2003. Expression of the specific type IV phosphodiesterase gene PDE4B3 during different phases of long-term potentiation in single hippocampal slices of rats in vitro. Neuroscience 117, 627-638.

Arp, J., Kirchhof, M.G., Baroja, M.L., Nazarian, S.H., Chau, T.A., Strathdee, C.A., Ball, E.H., Madrenas, J., 2003. Regulation of T-cell activation by phosphodiesterase 4B2 requires its dynamic redistribution during immunological synapse formation. Mol. Cell Biol. 23, 8042-8057.

Banner, K.H., Trevethick, M.A., 2004. PDE4 inhibition: a novel approach for the treatment of inflammatory bowel disease. Trends in Pharmacological Sciences 25, 430436. 
Bender, A.T., Beavo, J.A., 2006. Cyclic nucleotide phosphodiesterases: Molecular regulation to clinical use. Pharmacological Reviews 58, 488-520.

Boswell-Smith, V., Spina, D., Page, C.P., 2006. Phosphodiesterase inhibitors. British Journal of Pharmacology 147, S252-S257.

Breder, C.D., Hazuka, C., Ghayur, T., Klug, C., Huginin, M., Yasuda, K., Teng, M., Saper, C.B., 1994. Regional Induction of Tumor-Necrosis-Factor Alpha Expression in the Mouse-Brain After Systemic Lipopolysaccharide Administration. Proceedings of the National Academy of Sciences of the United States of America 91, 11393-11397.

Breder, C.D., Saper, C.B., 1996. Expression of inducible cyclooxygenase mRNA in the mouse brain after systemic administration of bacterial lipopolysaccharide. Brain Research 713, 64-69.

Buljevac, D., Flach, H.Z., Hop, W.C., Hijdra, D., Laman, J.D., Savelkoul, H.F., Der Meche, F.G., van Doorn, P.A., Hintzen, R.Q., 2002. Prospective study on the relationship between infections and multiple sclerosis exacerbations. Brain 125, 952960.

Cai, Z., Pang, Y., Lin, S., Rhodes, P.G., 2003. Differential roles of tumor necrosis factor-alpha and interleukin-1 beta in lipopolysaccharide-induced brain injury in the neonatal rat. Brain Res. 975, 37-47.

Cherry, J.A., Davis, R.L., 1999. Cyclic AMP phosphodiesterases are localized in regions of the mouse brain associated with reinforcement, movement, and affect. J. Comp Neurol. 407, 287-301.

Conti, M., 2000. Phosphodiesterases and cyclic nucleotide signaling in endocrine cells. Mol. Endocrinol. 14, 1317-1327. 
Conti, M., Beavo, J., 2007. Biochemistry and physiology of cyclic nucleotide Phosphocliesterases: Essential components in cyclic nucleotide signaling. Annual Review of Biochemistry 76, 481-511.

D'Sa, C., Tolbert, L.M., Conti, M., Duman, R.S., 2002. Regulation of cAMP-specific phosphodiesterases type 4B and 4D (PDE4) splice variants by cAMP signaling in primary cortical neurons. J. Neurochem. 81, 745-757.

D'Souza, S.D., Alinauskas, K.A., Antel, J.P., 1996. Ciliary neurotrophic factor selectively protects human oligodendrocytes from tumor necrosis factor-mediated injury. J. Neurosci. Res. 43, 289-298.

Elmquist, J.K., Breder, C.D., Sherin, J.E., Scammell, T.E., Hickey, W.F., Dewitt, D., Saper, C.B., 1997. Intravenous lipopolysaccharide induces cyclooxygenase 2-like immunoreactivity in rat brain perivascular microglia and meningeal macrophages. Journal of Comparative Neurology 381, 119-129.

Franklin K. B. J. and Paxinos G. 2007. The Mouse Brain in stereotaxic coordinates, Academic Press.

Goppelt-Struebe, M., 1995. Regulation of prostaglandin endoperoxide synthase (cyclooxygenase) isozyme expression. Prostaglandins Leukot. Essent. Fatty Acids 52, 213-222.

Graeber, M.B., Streit, W.J., 1990. Perivascular microglia defined. Trends Neurosci. 13, 366.

Hart, B.L., 1988. Biological basis of the behavior of sick animals. Neurosci. Biobehav. Rev. 12, 123-137.

Hebenstreit, G.F., Fellerer, K., Fichte, K., Fischer, G., Geyer, N., Meya, U., Hernandez, M., Schony, W., Schratzer, M., Soukop, W., 1989. Rolipram in major depressive 
disorder: results of a double-blind comparative study with imipramine. Pharmacopsychiatry 22, 156-160.

Houslay, M.D., 1998. Adaptation in cyclic AMP signalling processes: a central role for cyclic AMP phosphodiesterases. Semin. Cell Dev. Biol. 9, 161-167.

Houslay, M.D., Adams, D.R., 2003. PDE4 cAMP phosphodiesterases: modular enzymes that orchestrate signalling cross-talk, desensitization and compartmentalization. Biochemical Journal 370, 1-18.

Huston, E., Lumb, S., Russell, A., Catterall, C., Ross, A.H., Steele, M.R., Bolger, G.B., Perry, M.J., Owens, R.J., Houslay, M.D., 1997. Molecular cloning and transient expression in COS7 cells of a novel human PDE4B cAMP-specific phosphodiesterase, HSPDE4B3. Biochem. J. 328 ( Pt 2), 549-558.

Jin, S.L., Lan, L., Zoudilova, M., Conti, M., 2005. Specific role of phosphodiesterase 4B in lipopolysaccharide-induced signaling in mouse macrophages. J. Immunol. 175, $1523-1531$.

Jin, S.L., Conti, M., 2002. Induction of the cyclic nucleotide phosphodiesterase PDE4B is essential for LPS-activated TNF-alpha responses. Proceedings of the National Academy of Sciences of the United States of America 99, 7628-7633.

Johnson, A.K., Gross, P.M., 1993. Sensory circumventricular organs and brain homeostatic pathways. FASEB J. 7, 678-686.

Khan, N.A., Khan, A., Savelkoul, H.F., Benner, R., 2002. Inhibition of septic shock in mice by an oligopeptide from the beta-chain of human chorionic gonadotrophin hormone. Hum. Immunol. 63, 1-7.

Kloss, C.U., Bohatschek, M., Kreutzberg, G.W., Raivich, G., 2001. Effect of lipopolysaccharide on the morphology and integrin immunoreactivity of ramified microglia in the mouse brain and in cell culture. Exp. Neurol. 168, 32-46. 
Konsman, J.P., Parnet, P., Dantzer, R., 2002. Cytokine-induced sickness behaviour: mechanisms and implications. Trends Neurosci. 25, 154-159.

Laflamme, N., Lacroix, S., Rivest, S., 1999. An essential role of interleukin-1beta in mediating NF-kappaB activity and COX-2 transcription in cells of the blood-brain barrier in response to a systemic and localized inflammation but not during endotoxemia. J. Neurosci. 19, 10923-10930.

Lambertsen, K.L., Clausen, B.H., Babcock, A.A., Gregersen, R., Fenger, C., Nielsen, H.H., Haugaard, L.S., Wirenfeldt, M., Nielsen, M., Dagnaes-Hansen, F., Bluethmann, H., Faergeman, N.J., Meldgaard, M., Deierborg, T., Finsen, B., 2009. Microglia protect neurons against ischemia by synthesis of tumor necrosis factor. J. Neurosci. 29, 13191330.

Landry, M., Holmberg, K., Zhang, X., Hokfelt, T., 2000. Effect of axotomy on expression of NPY, galanin, and NPY Y1 and Y2 receptors in dorsal root ganglia and the superior cervical ganglion studied with double-labeling in situ hybridization and immunohistochemistry. Exp. Neurol. 162, 361-384.

Liberto, C.M., Albrecht, P.J., Herx, L.M., Yong, V.W., Levison, S.W., 2004. Proregenerative properties of cytokine-activated astrocytes. J. Neurochem. 89, 1092-1100.

Miró X, Perez-Torres, S., Puigdomenech, P., Palacios, J.M., Mengod, G., 2002.

Differential distribution of PDE4D splice variant mRNAs in rat brain suggests association with specific pathways and presynaptical localization. Synapse 45, 259-269. Miró, X., Perez-Torres, S., Palacios, J.M., Puigdomenech, P., Mengod, G., 2001. Differential distribution of cAMP-specific phosphodiesterase 7A mRNA in rat brain and peripheral organs. Synapse 40, 201-214.

Mori, F., Perez-Torres, S., De Caro, R., Porzionato, A., Macchi, V., Beleta, J., Gavalda, A., Palacios, J.M., Mengod, G., 2010. The human area postrema and other nuclei related 
to the emetic reflex express cAMP phosphodiesterases 4B and 4D. J. Chem. Neuroanat. $40,36-42$.

Oger, S., Mehats, C., Dallot, E., Ferre, F., Leroy, M.J., 2002. Interleukin-1beta induces phosphodiesterase 4B2 expression in human myometrial cells through a prostaglandin E2- and cyclic adenosine 3',5'-monophosphate-dependent pathway. J. Clin. Endocrinol. Metab 87, 5524-5531.

Park, J.H., Shin, S.H., 1996. Induction of IL-12 gene expression in the brain in septic shock. Biochem. Biophys. Res. Commun. 224, 391-396.

Pérez-Torres, S., Miró X, Palacios, J.M., Cortés, R., Puigdoménech, P., Mengod, G., 2000. Phosphodiesterase type 4 isozymes expression in human brain examined by in situ hybridization histochemistry and[3H]rolipram binding autoradiography. Comparison with monkey and rat brain. Journal of Chemical Neuroanatomy 20, 349374.

Pompeiano, M., Palacios, J.M., Mengod, G., 1992. Distribution and cellular localization of mRNA coding for 5-HT1A receptor in the rat brain: correlation with receptor binding. J. Neurosci. 12, 440-453.

Quan, N., Whiteside, M., Herkenham, M., 1998a. Cyclooxygenase 2 mRNA expression in rat brain after peripheral injection of lipopolysaccharide. Brain Res. 802, 189-197.

Quan, N., Whiteside, M., Herkenham, M., 1998b. Time course and localization patterns of interleukin-1beta messenger RNA expression in brain and pituitary after peripheral administration of lipopolysaccharide. Neuroscience 83, 281-293.

Reyes-Irisarri, E., Perez-Torres, S., Mengod, G., 2005. Neuronal expression of cAMPspecific phosphodiesterase 7b mRNA in the rat brain. Neuroscience 132, 1173-1185.

Reyes-Irisarri, E., Perez-Torres, S., Miro, X., Martinez, E., Puigdomenech, P., Palacios, J.M., Mengod, G., 2008. Differential distribution of PDE4B splice variant mRNAs in 
rat brain and the effects of systemic administration of LPS in their expression. Synapse $62,74-79$.

Reyes-Irisarri, E., Sanchez, A.J., Garcia-Merino, J.A., Mengod, G., 2007. Selective induction of cAMP phosphodiesterase PDE4B2 expression in experimental autoimmune encephalomyelitis. J. Neuropathology and Experimental Neurology 66, 923-931.

Schiltz, J.C., Sawchenko, P.E., 2002. Distinct brain vascular cell types manifest inducible cyclooxygenase expression as a function of the strength and nature of immune insults. J. Neurosci. 22, 5606-5618.

Schmitz, G.G., Walter, T., Seibl, R., Kessler, C., 1991. Nonradioactive labeling of oligonucleotides in vitro with the hapten digoxigenin by tailing with terminal transferase. Anal. Biochem. 192, 222-231.

Semmler, A., Okulla, T., Sastre, M., Dumitrescu-Ozimek, L., Heneka, M.T., 2005. Systemic inflammation induces apoptosis with variable vulnerability of different brain regions. J. Chem. Neuroanat. 30, 144-157.

Serrats, J., Artigas, F., Mengod, G., Cortes, R., 2003. GABAB receptor mRNA in the raphe nuclei: co-expression with serotonin transporter and glutamic acid decarboxylase. J. Neurochem. 84, 743-752.

Sly, L.M., Krzesicki, R.F., Brashler, J.R., Buhl, A.E., McKinley, D.D., Carter, D.B., Chin, J.E., 2001. Endogenous brain cytokine mRNA and inflammatory responses to lipopolysaccharide are elevated in the Tg2576 transgenic mouse model of Alzheimer's disease. Brain Res. Bull. 56, 581-588.

Swinnen, J.V., Joseph, D.R., Conti, M., 1989. The mRNA encoding a high-affinity cAMP phosphodiesterase is regulated by hormones and cAMP. Proc. Natl. Acad. Sci. U. S. A $86,8197-8201$. 


\begin{abstract}
Takahashi, M., Terwilliger, R., Lane, C., Mezes, P.S., Conti, M., Duman, R.S., 1999.
\end{abstract} Chronic antidepressant administration increases the expression of cAMP-specific phosphodiesterase 4A and 4B isoforms. J. Neurosci. 19, 610-618.

Tomiyama, M., Palacios, J.M., Cortes, R., Vilaro, M.T., Mengod, G., 1997. Distribution of AMPA receptor subunit mRNAs in the human basal ganglia: an in situ hybridization study. Brain Res. Mol. Brain Res. 46, 281-289.

Torphy, T.J., 1998. Phosphodiesterase isozymes - Molecular targets for novel antiasthma agents. American Journal of Respiratory and Critical Care Medicine 157, $351-370$

Villa, P., Ghezzi, P., 2004. Animal models of endotoxic shock. Methods Mol. Med. 98, 199-206.

Yamamoto, S., Sugahara, S., Ikeda, K., Shimizu, Y., 2006. Pharmacological profile of a novel phosphodiesterase 7A and-4 dual inhibitor, YM-393059, on acute and chronic inflammation models. European Journal of Pharmacology 550, 166-172. 
Table 1 List of the oligonucleotides used

\begin{tabular}{|c|c|c|c|}
\hline mRNA & $\begin{array}{l}\text { Oligonucleotide } \\
\text { name }\end{array}$ & $\begin{array}{l}\text { Accession } \\
\text { number }\end{array}$ & Bp limits \\
\hline PDE4A & PDE4A/1 & L27057 & $3649-3693$ \\
\hline \multirow[t]{2}{*}{ PDE4B } & PDE4B/3 & NM_017031 & $2639-2687$ \\
\hline & $\mathrm{PDE} 4 \mathrm{~B} / 4$ & NM_017031 & $2537-2581$ \\
\hline PDE4B1 & PDE4B1/4 & AF202732 & $506-550$ \\
\hline PDE4B2 & PDE4B2/2 & L27058 & 545-589 \\
\hline \multirow[t]{3}{*}{ PDE4B3 } & PDE4B3/1 & U95748 & 700-744 \\
\hline & PDE4B3/2 & U95748 & $616-660$ \\
\hline & PDE4B3/3 & U95748 & $556-600$ \\
\hline \multirow[t]{2}{*}{ PDE4B4 } & PDE4B4/1 & AF202733 & $264-308$ \\
\hline & PDE4B4/3 & AF202733 & 171-215 \\
\hline PDE4D & PDE4D/2 & NM_017032 & $1917-1961$ \\
\hline TNF- $\alpha$ & TNF- $\alpha / 1$ & NM_013693 & $397-441$ \\
\hline \multirow[t]{3}{*}{ cox-2 } & COX-2/1 & NM_017232 & $1848-1893$ \\
\hline & cox-2/2 & NM_017232 & $2710-2754$ \\
\hline & $\operatorname{coX}-2 / 3$ & NM_017232 & $446-490$ \\
\hline IL-1 $\beta$ & $I L-1 \beta / 1$ & NM_008361 & $72-116$ \\
\hline \multirow[t]{3}{*}{ VCAM-1 } & VCAM-1/1 & M84487 & $63-107$ \\
\hline & VCAM-1/2 & M84487 & $428-472$ \\
\hline & VCAM-1/3 & M84487 & $1107-1151$ \\
\hline \multirow[t]{2}{*}{ GFAP } & GFAP/1 & NM_017009 & 233-279 \\
\hline & GFAP/2 & NM_017009 & $1199-1248$ \\
\hline \multirow[t]{4}{*}{ PAFR } & PAFR/1 & U04740 & $124-168$ \\
\hline & PAFR/2 & U04740 & $1081-1125$ \\
\hline & PAFR/3 & U04740 & $786-840$ \\
\hline & PAFR/4 & U04740 & $976-1020$ \\
\hline MBP & $\mathrm{MBP} / 1$ & M25889 & $179-223$ \\
\hline MAP-2 & MAP-2/1 & NM_013066 & $195-239$ \\
\hline
\end{tabular}

COX, cyclooxygenase; GFAP, glial fibrillary acidic protein; IL, interleukin; MAP, microtubule-associated protein; MBP, myelin basic protein; PAFR, platelet-activating factor receptor; PDE, phosphodiesterase; TNF, tumor necrosis factor; VCAM, vascular cell adhesion molecule. 
Table 2 Quantification of the presence of PDE4B2 or PDE4B3 mRNA in different cellular populations

\begin{tabular}{|c|c|c|c|c|c|c|c|c|c|c|c|c|}
\hline & \multicolumn{6}{|c|}{ PDE4B2 } & \multicolumn{6}{|l|}{ PDE4B3 } \\
\hline & \multicolumn{3}{|c|}{ Leptomeningeal cells } & \multicolumn{3}{|c|}{ Nuclei of the inferior colliculus } & \multicolumn{3}{|c|}{ Cingulate Cortex } & \multicolumn{3}{|c|}{ Nuclei of the inferior colliculius } \\
\hline & Control & $3 \mathrm{~h}$ & $8 \mathrm{~h}$ & Control & $3 \mathrm{~h}$ & $8 \mathrm{~h}$ & Control & $3 \mathrm{~h}$ & $8 \mathrm{~h}$ & Control & $3 \mathrm{~h}$ & $8 \mathrm{~h}$ \\
\hline VCAM & ND & $61 \pm 8$ & $56 \pm 13$ & ND & $17 \pm 13$ & $35 \pm 11$ & & & & & & \\
\hline PAFR & $17 \pm 15$ & $54 \pm 14$ & $44 \pm 7$ & $23 \pm 5$ & $28 \pm 7$ & $39 \pm 8$ & & & & & & \\
\hline GFAP & $9 \pm 7$ & $37 \pm 11$ & $23 \pm 8$ & ND & $53 \pm 14$ & $33 \pm 13$ & ND & ND & ND & ND & $7 \pm 2$ & $8 \pm 1$ \\
\hline MBP & & & & & & & $80 \pm 3$ & $55 \pm 13$ & $59 \pm 9$ & $71 \pm 1$ & $53 \pm 6$ & $40 \pm 4$ \\
\hline MAP & & & & & & & $35 \pm 14$ & $43 \pm 1$ & $36 \pm 10$ & $44 \pm 8$ & $35 \pm 13$ & $38 \pm 7$ \\
\hline
\end{tabular}

Quantification was performed in leptomeninges, cingulate cortex and nuclei of the inferior colliculus of mice sacrificed, 3 and $8 \mathrm{~h}$ after intra peritoneal LPS administration and control animals. Data are the mean \pm SD of five animals and represent the percentage of counted cells, endothelial cells (VCAM), microglia/macrophages (PAFR), astrocytes (GFAP), oligodendrocytes (MBP) and neurons (MAP), expressing PDE4B2 or PDE4B3 mRNA. Each percentage was determined from a mean of 61.1 cells, except for VCAM and GFAP positive cells in the nuclei of the inferior colliculus and in the leptomeningeal areas of control animals where the mean was 28.7 cells (5284 cells counted). GFAP, glial fibrillary acidic protein; MAP, microtubule-associated protein; MBP, myelin basic protein; ND, not detected; PAFR, platelet-activating factor receptor; PDE, phosphodiesterase; VCAM, vascular cell adhesion molecule. 


\section{FIGURE LEGENDS}

Figure 1. Presence of necrotic and apoptotic cells following LPS administration. Photomicrographs were taken from coronal sections of the dentate gyrus of animals sacrificed $24 \mathrm{~h}$ post-injection. (A) Fluoro-Jade B, (B) TUNEL and DAPI staining. LPS, lipopolysaccharide. Scale bar $=100 \mu \mathrm{m}$.

\section{Figure 2. Expression of inflammatory markers and GFAP mRNAs following LPS}

administration. Macroscopic photographs of film autoradiographic show localization of the mRNAs coding for the inflammatory markers, COX-2, IL-1 $\beta$, TNF- $\alpha$, VCAM-1 and GFAP following i.p. LPS administration in mouse coronal sections. (B,D,F,H) COX-2, IL-1 $\beta$, TNF- $\alpha$ and VCAM-1 mRNAs expression is prominent in the leptomeninges (white arrowheads) and in blood vessels (black arrowheads) 3h after LPS administration. (J) GFAP mRNA hybridization levels show a later response with the maximum alterations observed $24 \mathrm{~h}$ after LPS provoked immune activation. (A,C,E,G,I): Control: Saline administered i.p. (B,D,F,H): Animals treated i.p. with LPS 3 hours (J): 24 hours treatment. COX, cyclooxygenase; GFAP, glial fibrillary acidic protein; IL-1 $\beta$, interleukin; LPS, lipopolysaccharide; TNF- $\alpha$, tumor necrosis factor; VCAM, vascular cell adhesion molecule. Scale bar $=5 \mathrm{~mm}$.

Figure 3. Activation of microglia following LPS administration. Analysis of the effect of LPS administration on lectin-stained microglia. Photomicrographs were taken of coronal sections of the leptomeninges and the immediately proximate area of animals sacrificed at (B) 3h and (C) 8h post-injection. Note the morphological changes observed in microglial ramification following LPS administration (Black arrowheads). (A) Control: Saline administered i.p.. LPS, lipopolysaccharide. Scale bars $=100 \mu \mathrm{m}$ and 1 $\mu \mathrm{m}$. 
Figure 4. Expression of PDE4B splice variant mRNAs in mouse brain. Macroscopic photographs of film autoradiographic images of coronal sections showing mRNA hybridization pattern of PDE4B splice variants (A,E,I,M,Q) PDE4B1, (B,F,J,N,R) PDE4B2, (C,G,K,O,S) PDE4B3, and (D,H,L,P,T) PDE4B4 under basal conditions in C57BL6 mice. Note the strong labeling in the cerebellar granular layer for all four variants. cc, corpus callosum; $\mathrm{Cg}$, cingulate cortex; $\mathrm{cp}$, cerebral peduncle; $\mathrm{DG}$, dentate gyrus; lepto., leptomeninges; LPS, lipopolysaccharide; Pir, piriform cortex and PV, paraventricular thalamic nuclei. Scale bar $=5 \mathrm{~mm}$.

Figure 5. Expression of PDE4B2 and PDE4B3 mRNAs following LPS administration. Macroscopic photographs of film autoradiographic images of mouse coronal sections showing alterations in mRNA hybridization levels of PDE4B2 and PDE4B3 splice variants in (A,B) control animals (saline administered i.p.) and (C,D) LPS treated animals 3 hours and (E,F) 8 hours after injection. (C) Clearly augmented mRNA expression in the leptomeninges (lepto.) is observed for the PDE4B2 splice variant $3 \mathrm{~h}$ after injection, (D) whereas mRNA hybridization levels of the PDE4B3 splice variant show a slight downregulation at this time point. (E) 8 h after injection an overall increase in hybridization levels for the PDE4B2 splice variant is observed in the parenchyma (IC), the areas in close contact with the brain exterior such as the leptomeninges and brain microvessels $(\mathbf{m v})$. Note the general decrease in mRNA expression in whole brain section for $(\mathbf{F})$ the PDE4B3 splice variant $8 \mathrm{~h}$ after LPS administration compared to (B) saline treated mice. IC, nuclei of the inferior colliculus; lepto., leptomeninges; LPS, lipopolysaccharide; mv, microvessel PDE, phosphodiesterase. Scale bar $=5 \mathrm{~mm}$.

Figure 6. Alterations in expression of PDE4B2 and PDE4B3 mRNA following LPS administration. Effects of LPS administration on the mRNA expression of PDE4B 
splice variants (A) PDE4B2 and (B) PDE4B3 in different mouse brain areas 1, 3, 8 and $24 \mathrm{~h}$ post-injection. Relative optical densities of the mRNA levels in autoradiographic films were determined with AIS computerized image analysis system. Data show the mean $\pm \mathrm{SD}$ ( $\mathrm{n}=5$ mice/group). Note the opposite effects provoked by LPS administration on mRNA expression for the two PDE4B splice variants. Statistically significant differences between the LPS-stimulated and the control groups are represented by $* \mathrm{P}<0.05, * * \mathrm{P}<0.01, * * * \mathrm{P}<0.001$; Bonferroni posttest. CA1-2, CA3, fields of Cornu ammonis; $\mathrm{Cg}$, cingulate cortex; $\mathrm{CPu}$, caudate putamen; $\mathrm{DG}$, dentate gyrus; hf, hippocampal fissure; IC, nuclei of the inferior colliculus; lepto., leptomeninges; LPS, lipopolysaccharide; PDE, phosphodiesterase; SFO, subfornical organ.

Figure 7. Characterization of cells displaying LPS-altered expression of PDE4B2. Cellular localization of PDE4B2 mRNA in activated endothelial, microglial and astrocytic cell populations in mouse leptomeninges $3 \mathrm{~h}$ post-injection. Highmagnification bright-field microphotographs of emulsion dipped sections, simultaneously showing mRNA visualized by double in situ hybridization using ${ }^{33} \mathrm{P}$ labeled oligonucleotides complementary to the mRNA coding for PDE4B2 (clusters of dark silver grains), and DIG-labeled oligonucleotides (dark-purple precipitate) for (A) VCAM mRNA, endothelial cells, (B) PAFR mRNA, microglial/macrophage cells, or (C) GFAP mRNA, astrocytes. Black arrowheads point to digoxigenin-labeled cells, white arrowheads to radioactively-labeled cells and double white and black arrowheads to double-labeled cells. GFAP, glial fibrillary acidic protein; LPS, lipopolysaccharide; PAFR, platelet-activating factor receptor; PDE, phosphodiesterase; VCAM, vascular cell adhesion molecule. Bar $=20 \mu \mathrm{m}$. 
Figure 8. Characterization of cells displaying LPS-altered expression of PDE4B3. Cellular localization of PDE4B3 mRNA (cluster of dark silver grains) in, (A,D) oligodendrocytes, MBP mRNA positive cells; (B,E) neurons, MAP mRNA positive cells and (C,F) astrocytes, GFAP mRNA positive cells in mouse brain parenchyma (IC) in control and $3 \mathrm{~h}$ post-injection. Black arrowheads point to digoxigenin-labeled cells (dark-purple precipitate), white arrowheads to radioactively-labeled cells and double white and black arrowheads to double-labeled cells. Note the reduction in PDE4B3 mRNA after LPS injection (D,E,F). GFAP, glial fibrillary acidic protein; LPS, lipopolysaccharide; MAP, microtubule-associated protein; MBP, myelin basic protein; PDE, phosphodiesterase. Bar $=20 \mu \mathrm{m}$. 
Table 1 List of the oligonucleotides used

\begin{tabular}{|c|c|c|c|}
\hline mRNA & $\begin{array}{l}\text { Oligonucleotide } \\
\text { name }\end{array}$ & $\begin{array}{l}\text { Accession } \\
\text { number }\end{array}$ & Bp limits \\
\hline PDE4A & PDE4A/1 & L27057 & $3649-3693$ \\
\hline \multirow[t]{2}{*}{ PDE4B } & PDE4B/3 & NM_017031 & $2639-2687$ \\
\hline & $\mathrm{PDE} 4 \mathrm{~B} / 4$ & NM_017031 & $2537-2581$ \\
\hline PDE4B1 & PDE4B1/4 & AF202732 & $506-550$ \\
\hline PDE4B2 & PDE4B2/2 & L27058 & 545-589 \\
\hline \multirow[t]{3}{*}{ PDE4B3 } & PDE4B3/1 & U95748 & 700-744 \\
\hline & PDE4B3/2 & U95748 & $616-660$ \\
\hline & PDE4B3/3 & U95748 & $556-600$ \\
\hline \multirow[t]{2}{*}{ PDE4B4 } & PDE4B4/1 & AF202733 & $264-308$ \\
\hline & PDE4B4/3 & AF202733 & 171-215 \\
\hline PDE4D & PDE4D/2 & NM_017032 & $1917-1961$ \\
\hline TNF- $\alpha$ & TNF- $\alpha / 1$ & NM_013693 & $397-441$ \\
\hline \multirow[t]{3}{*}{ cox-2 } & COX-2/1 & NM_017232 & $1848-1893$ \\
\hline & cox-2/2 & NM_017232 & $2710-2754$ \\
\hline & $\operatorname{coX}-2 / 3$ & NM_017232 & $446-490$ \\
\hline IL-1 $\beta$ & $I L-1 \beta / 1$ & NM_008361 & $72-116$ \\
\hline \multirow[t]{3}{*}{ VCAM-1 } & VCAM-1/1 & M84487 & $63-107$ \\
\hline & VCAM-1/2 & M84487 & $428-472$ \\
\hline & VCAM-1/3 & M84487 & $1107-1151$ \\
\hline \multirow[t]{2}{*}{ GFAP } & GFAP/1 & NM_017009 & 233-279 \\
\hline & GFAP/2 & NM_017009 & $1199-1248$ \\
\hline \multirow[t]{4}{*}{ PAFR } & PAFR/1 & U04740 & $124-168$ \\
\hline & PAFR/2 & U04740 & $1081-1125$ \\
\hline & PAFR/3 & U04740 & $786-840$ \\
\hline & PAFR/4 & U04740 & $976-1020$ \\
\hline MBP & $\mathrm{MBP} / 1$ & M25889 & $179-223$ \\
\hline MAP-2 & MAP-2/1 & NM_013066 & $195-239$ \\
\hline
\end{tabular}

COX, cyclooxygenase; GFAP, glial fibrillary acidic protein; IL, interleukin; MAP, microtubule-associated protein; MBP, myelin basic protein; PAFR, platelet-activating factor receptor; PDE, phosphodiesterase; TNF, tumor necrosis factor; VCAM, vascular cell adhesion molecule. 
Table 2 Quantification of the presence of PDE4B2 or PDE4B3 mRNA in different cellular populations

\begin{tabular}{|c|c|c|c|c|c|c|c|c|c|c|c|c|}
\hline & \multicolumn{6}{|l|}{ PDE4B2 } & \multicolumn{6}{|l|}{ PDE4B3 } \\
\hline & \multicolumn{3}{|c|}{ Leptomeningeal cells } & \multicolumn{3}{|c|}{ Nuclei of the inferior colliculus } & \multicolumn{3}{|c|}{ Cingulate Cortex } & \multicolumn{3}{|c|}{ Nuclei of the inferior colliculius } \\
\hline & Control & $3 \mathrm{~h}$ & $8 \mathrm{~h}$ & Control & $3 \mathrm{~h}$ & $8 \mathrm{~h}$ & Control & $3 \mathrm{~h}$ & $8 \mathrm{~h}$ & Control & $3 \mathrm{~h}$ & $8 \mathrm{~h}$ \\
\hline VCAM & ND & $61 \pm 8$ & $56 \pm 13$ & ND & $17 \pm 13$ & $35 \pm 11$ & & & & & & \\
\hline PAFR & $17 \pm 15$ & $54 \pm 14$ & $44 \pm 7$ & $23 \pm 5$ & $28 \pm 7$ & $39 \pm 8$ & & & & & & \\
\hline GFAP & $9 \pm 7$ & $37 \pm 11$ & $23 \pm 8$ & ND & $53 \pm 14$ & $33 \pm 13$ & ND & ND & ND & ND & $7 \pm 2$ & $8 \pm 1$ \\
\hline MBP & & & & & & & $80 \pm 3$ & $55 \pm 13$ & $59 \pm 9$ & $71 \pm 1$ & $53 \pm 6$ & $40 \pm 4$ \\
\hline MAP & & & & & & & $35 \pm 14$ & $43 \pm 1$ & $36 \pm 10$ & $44 \pm 8$ & $35 \pm 13$ & $38 \pm 7$ \\
\hline
\end{tabular}

Quantification was performed in leptomeninges, cingulate cortex and nuclei of the inferior colliculus of mice sacrificed, 3 and $8 \mathrm{~h}$ after intra peritoneal LPS administration and control animals. Data are the mean \pm SD of five animals and represent the percentage of counted cells, endothelial cells (VCAM), microglia/macrophages (PAFR), astrocytes (GFAP), oligodendrocytes (MBP) and neurons (MAP), expressing PDE4B2 or PDE4B3 mRNA. Each percentage was determined from a mean of 61.1 cells, except for VCAM and GFAP positive cells in the nuclei of the inferior colliculus and in the leptomeningeal areas of control animals where the mean was 28.7 cells (5284 cells counted). GFAP, glial fibrillary acidic protein; MAP, microtubule-associated protein; MBP, myelin basic protein; ND, not detected; PAFR, platelet-activating factor receptor; PDE, phosphodiesterase; VCAM, vascular cell adhesion molecule. 

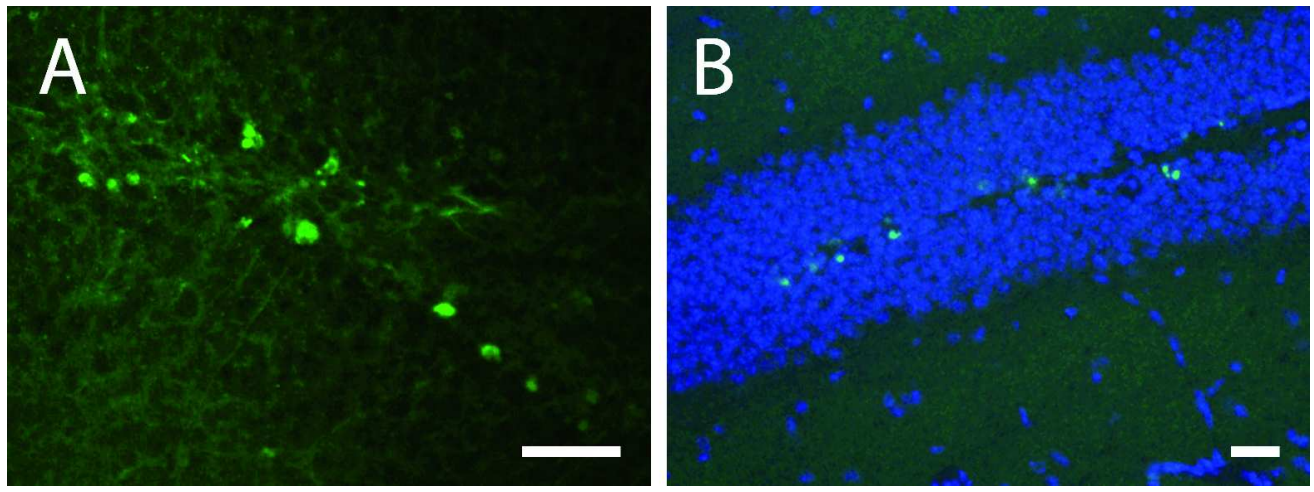

Figure 1. Presence of necrotic and apoptotic cells following LPS administration.

Photomicrographs were taken from coronal sections of the dentate gyrus of animals sacrificed $24 \mathrm{~h}$ post-injection. (A) Fluoro-Jade B, (B) TUNEL and DAPI staining. LPS, lipopolysaccharide. Scale bar $=100 \mu \mathrm{m}$.

$82 \times 30 \mathrm{~mm}(480 \times 480 \mathrm{DPI})$ 

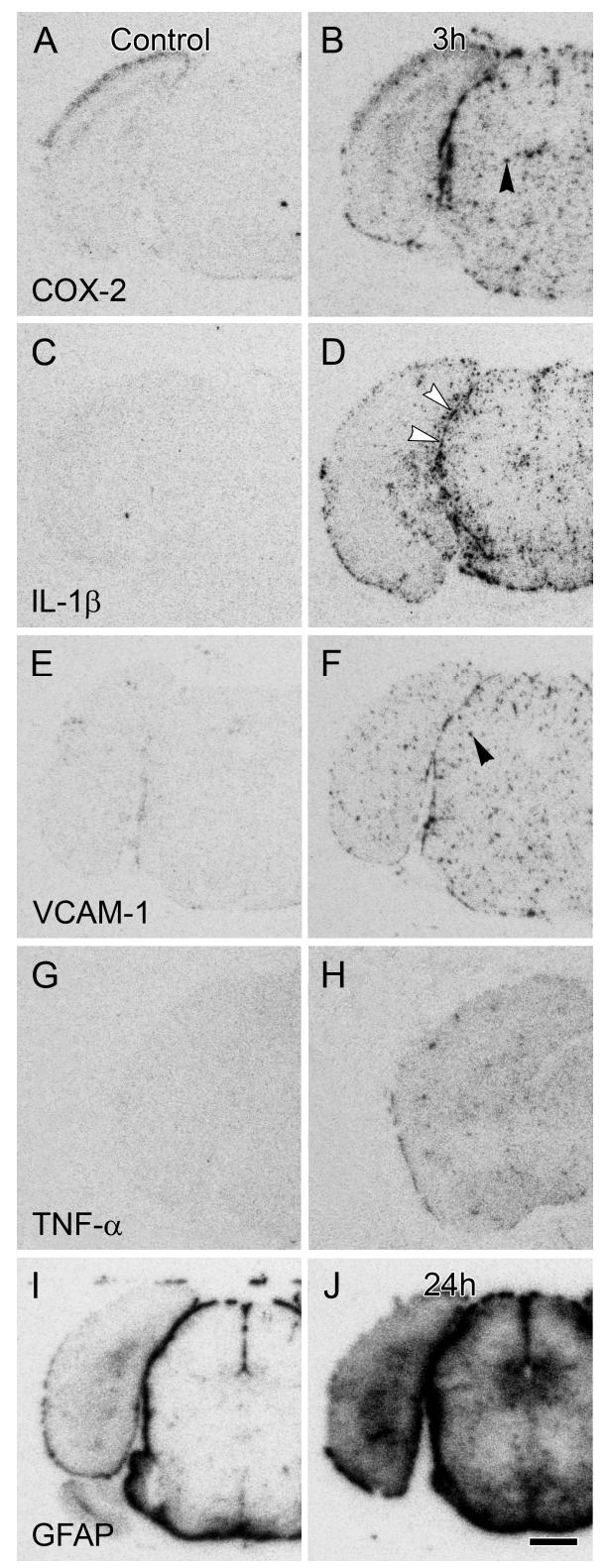

Figure 2. Expression of inflammatory markers and GFAP mRNAs following LPS administration. Macroscopic photographs of film autoradiographic show localization of the mRNAs coding for the inflammatory markers, COX-2, IL-1 $\beta$, TNF-a, VCAM-1 and GFAP following i.p. LPS administration in mouse coronal sections. (B, D, F, H) COX-2, IL-1 $\beta$, TNF- $a$ and VCAM- 1 mRNAs expression is prominent in the leptomeninges (white arrowheads) and in blood vessels (black arrowheads) 3h after LPS administration. (J) GFAP mRNA hybridization levels show a later response with the maximum alterations observed $24 \mathrm{~h}$ after LPS provoked immune activation. $(\mathbf{A}, \mathbf{C}, \mathbf{E}, \mathbf{G}, \mathbf{I})$ : Control: Saline administered i.p. (B,D,F,H): Animals treated i.p. with LPS 3 hours (J): 24 hours treatment. COX, cyclooxygenase; GFAP, glial fibrillary acidic protein; IL-1 $\beta$, interleukin; LPS, lipopolysaccharide; TNF-a, tumor necrosis factor; VCAM, vascular cell adhesion molecule. Scale bar $=5 \mathrm{~mm}$.

$82 \times 222 \mathrm{~mm}(480 \times 480 \mathrm{DPI})$ 

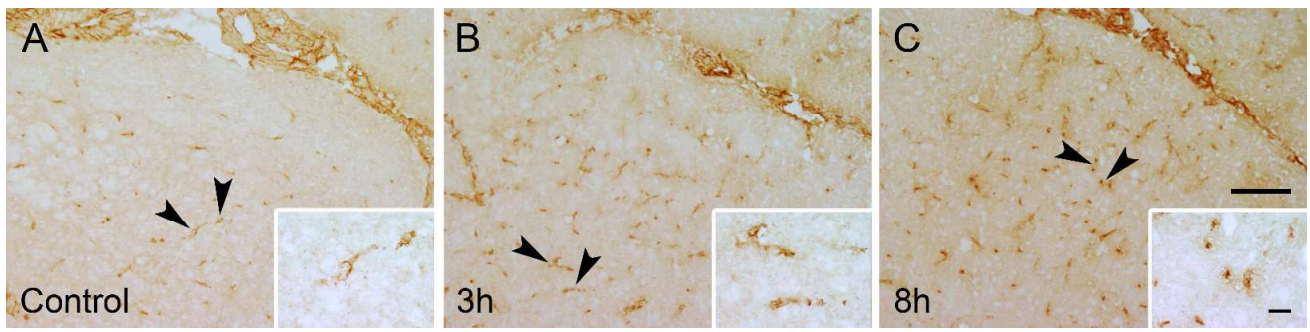

Figure 3. Activation of microglia following LPS administration. Analysis of the effect of LPS administration on lectin-stained microglia. Photomicrographs were taken of coronal sections of the leptomeninges and the immediately proximate area of animals sacrificed at (B) $3 \mathrm{~h}$ and (C) $8 \mathrm{~h}$ postinjection. Note the morphological changes observed in microglial ramification following LPS administration (Black arrowheads). (A) Control: Saline administered i.p.. LPS, lipopolysaccharide. Scale bars $=100 \mu \mathrm{m}$ and $1 \mu \mathrm{m}$. $172 \times 42 \mathrm{~mm}$ (480 x 480 DPI) 

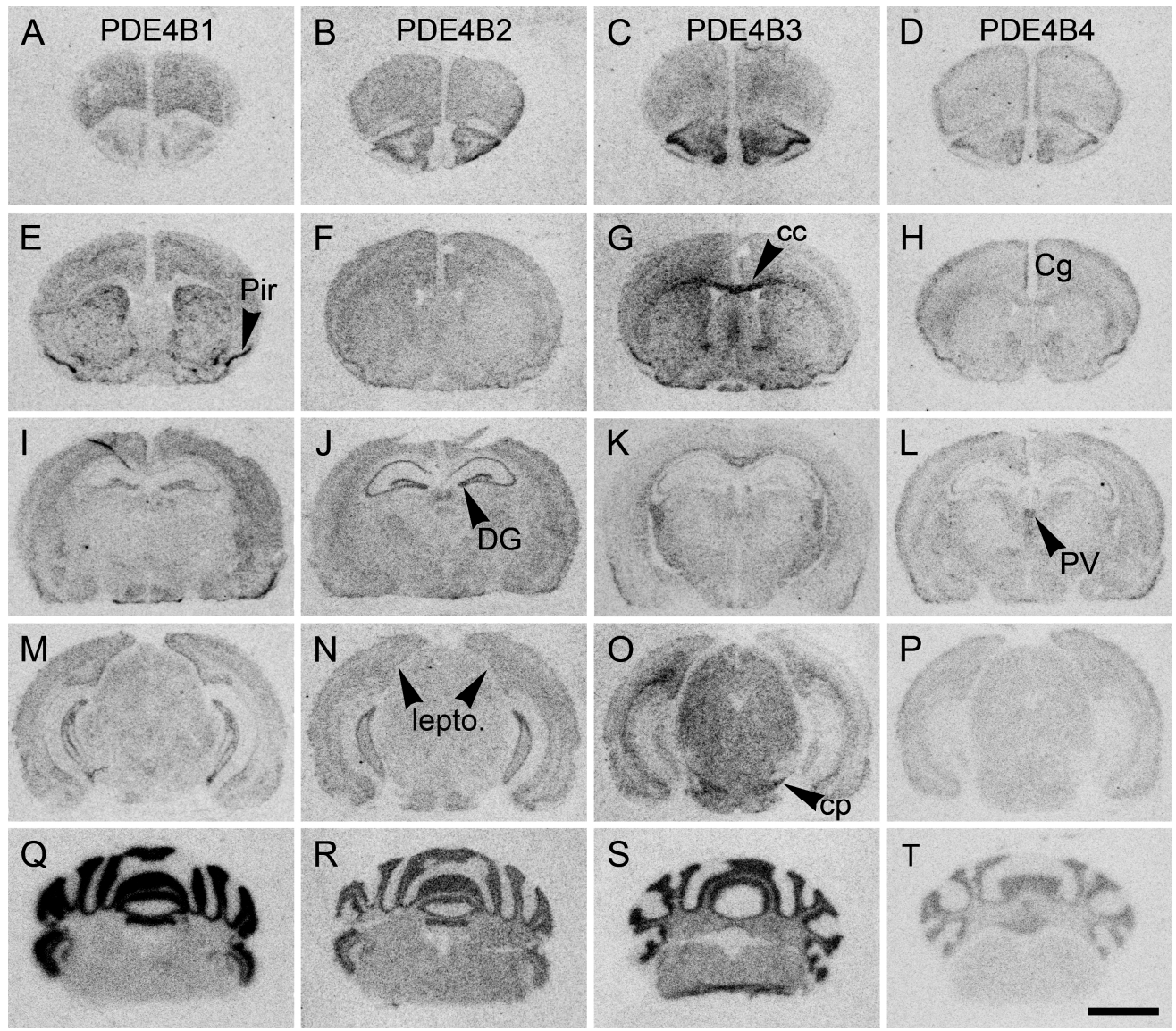

Figure 4. Expression of PDE4B splice variant mRNAs in mouse brain. Macroscopic photographs of film autoradiographic images of coronal sections showing mRNA hybridization pattern of PDE4B splice variants $(\mathbf{A}, \mathbf{E}, \mathbf{I}, \mathbf{M}, \mathbf{Q})$ PDE4B1, $(\mathbf{B}, \mathbf{F}, \mathbf{J}, \mathbf{N}, \mathbf{R})$ PDE4B2, $(\mathbf{C}, \mathbf{G}, \mathbf{K}, \mathbf{O}, \mathbf{S})$ PDE4B3, and $(\mathbf{D}, \mathbf{H}, \mathbf{L}, \mathbf{P}, \mathbf{T})$ PDE4B4 under basal conditions in C57BL6 mice. Note the strong labeling in the cerebellar granular layer for all four variants. $\mathrm{CC}$, corpus callosum; $\mathrm{Cg}$, cingulate cortex; $\mathrm{cp}$, cerebral peduncle; DG, dentate gyrus; lepto., leptomeninges; LPS, lipopolysaccharide; Pir, piriform cortex and PV, paraventricular thalamic nuclei. Scale bar $=5 \mathrm{~mm}$. $172 \times 151 \mathrm{~mm}(480 \times 480$ DPI $)$ 

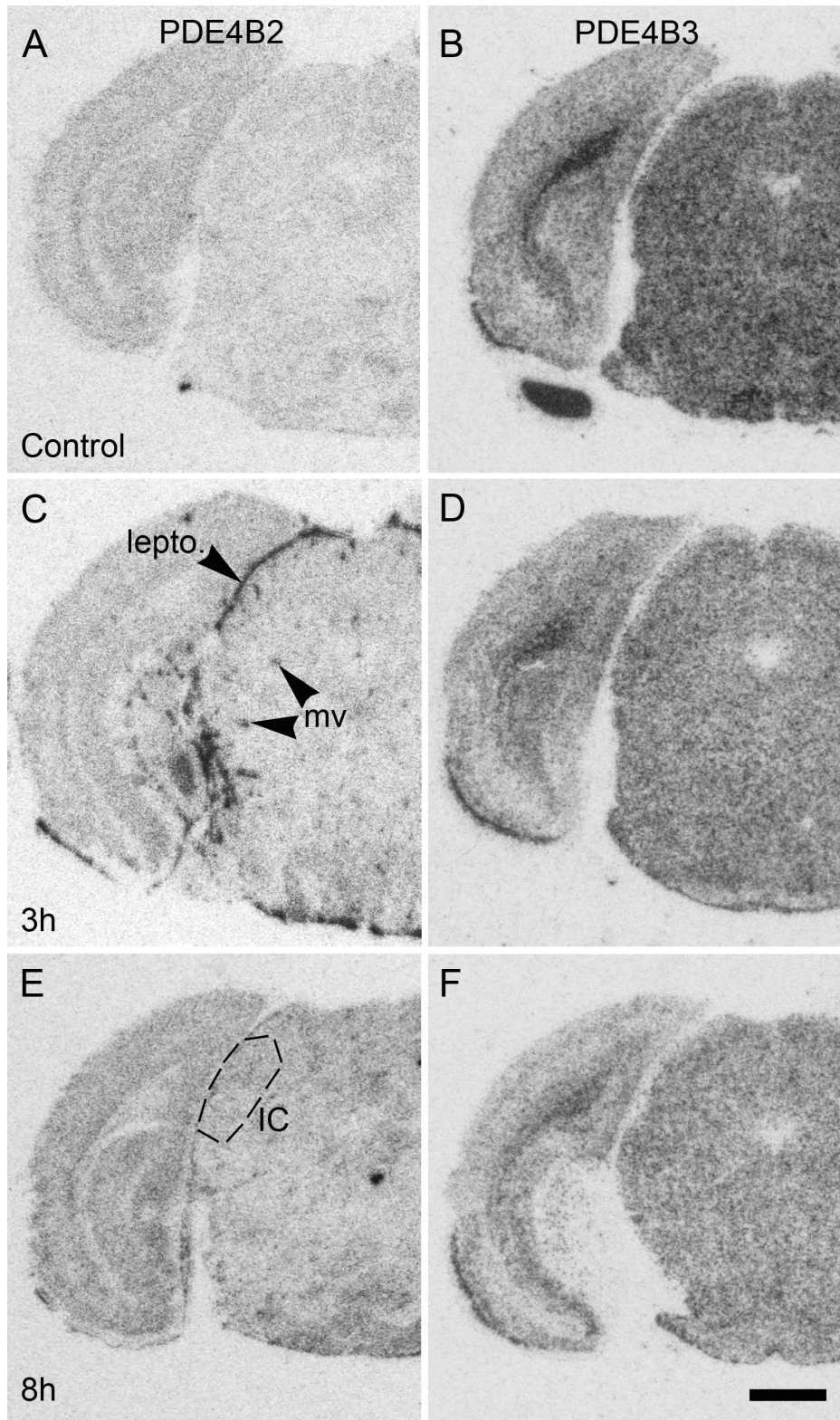

F

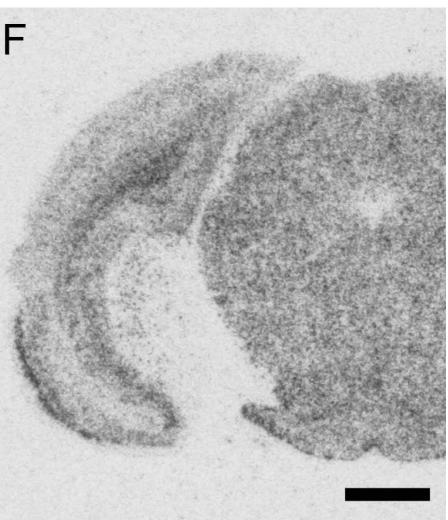

Figure 5. Expression of PDE4B2 and PDE4B3 mRNAs following LPS administration.

Macroscopic photographs of film autoradiographic images of mouse coronal sections showing alterations in mRNA hybridization levels of PDE4B2 and PDE4B3 splice variants in (A,B) control animals (saline administered i.p.) and (C,D) LPS treated animals 3 hours and $(\mathbf{E}, \mathbf{F}) 8$ hours after injection. (C) Clearly augmented mRNA expression in the leptomeninges (lepto.) is observed for the PDE4B2 splice variant 3h after injection, (D) whereas mRNA hybridization levels of the PDE4B3 splice variant show a slight downregulation at this time point. (E) $8 \mathrm{~h}$ after injection an overall increase in hybridization levels for the PDE4B2 splice variant is observed in the parenchyma (IC), the areas in close contact with the brain exterior such as the leptomeninges and brain microvessels $(\mathbf{m v})$. Note the general decrease in MRNA expression in whole brain section for $(\mathbf{F})$ the PDE4B3 splice variant $8 \mathrm{~h}$ after LPS administration compared to (B) saline treated mice. IC, nuclei of the inferior colliculus; lepto., leptomeninges; LPS, lipopolysaccharide; mv, microvessel PDE, phosphodiesterase. Scale bar $=5 \mathrm{~mm}$. 

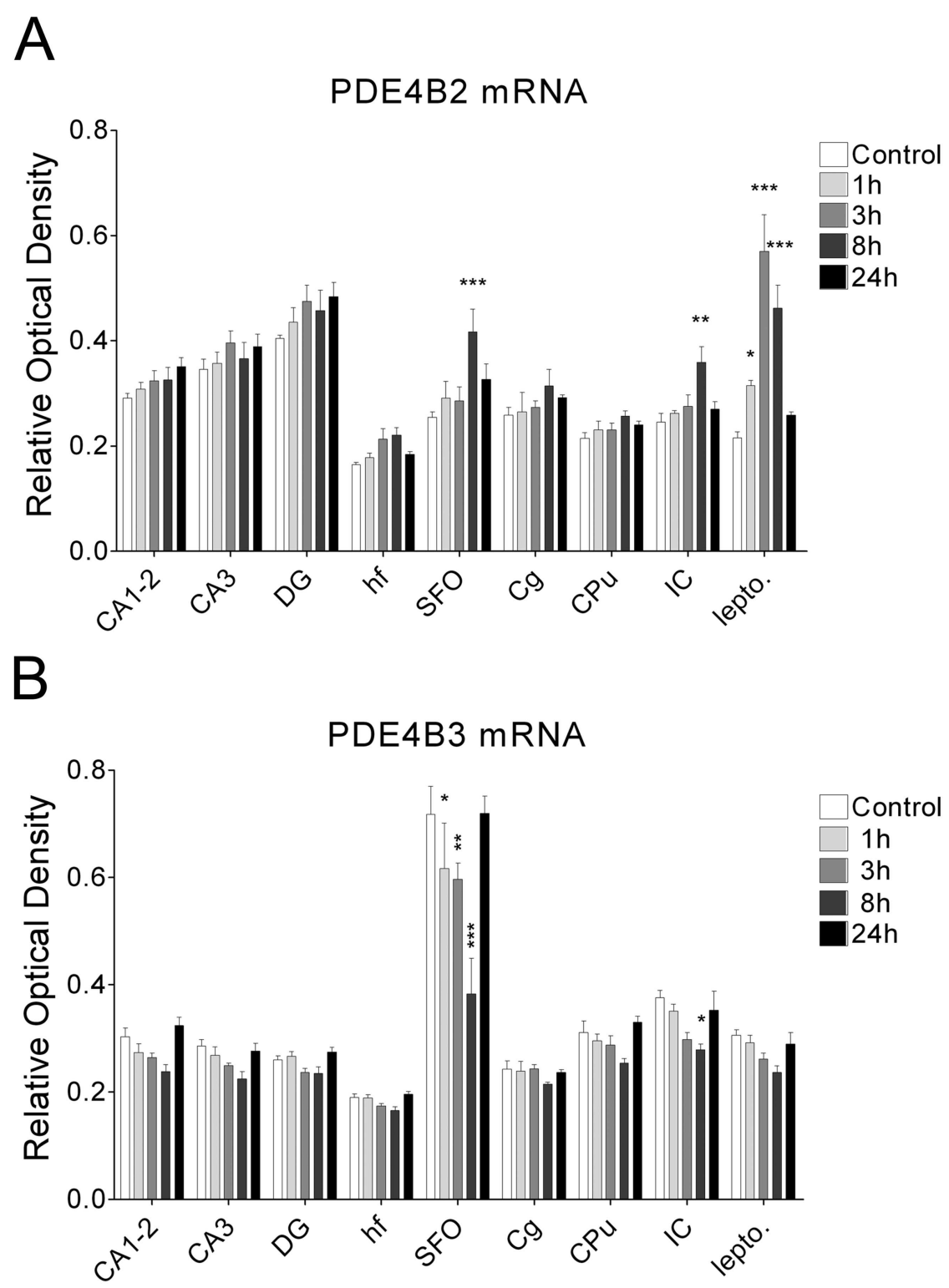

Figure 6. Alterations in expression of PDE4B2 and PDE4B3 mRNA following LPS administration. Effects of LPS administration on the mRNA expression of PDE4B splice variants (A) PDE4B2 and (B) PDE4B3 in different mouse brain areas 1, 3, 8 and 24h post-injection. Relative optical densities of the mRNA levels in autoradiographic films were determined with AIS computerized image analysis system. Data show the mean $\pm S D(n=5$ mice/group). Note the opposite effects provoked by LPS administration on mRNA expression for the two PDE4B splice variants. Statistically significant differences between the LPS-stimulated and the control groups are represented by $* \mathrm{P}<0.05, * * \mathrm{P}<0.01, * * * \mathrm{P}<0.001$; Bonferroni posttest. CA1-2, CA3, fields of Cornu ammonis; $\mathrm{Cg}$, cingulate cortex; $\mathrm{CPu}$, caudate putamen; DG, dentate gyrus; hf, hippocampal fissure; IC, nuclei of the inferior colliculus; lepto., leptomeninges; LPS, lipopolysaccharide; PDE, phosphodiesterase; SFO, subfornical organ. $113 \times 156 \mathrm{~mm}(600 \times 600 \mathrm{DPI})$ 

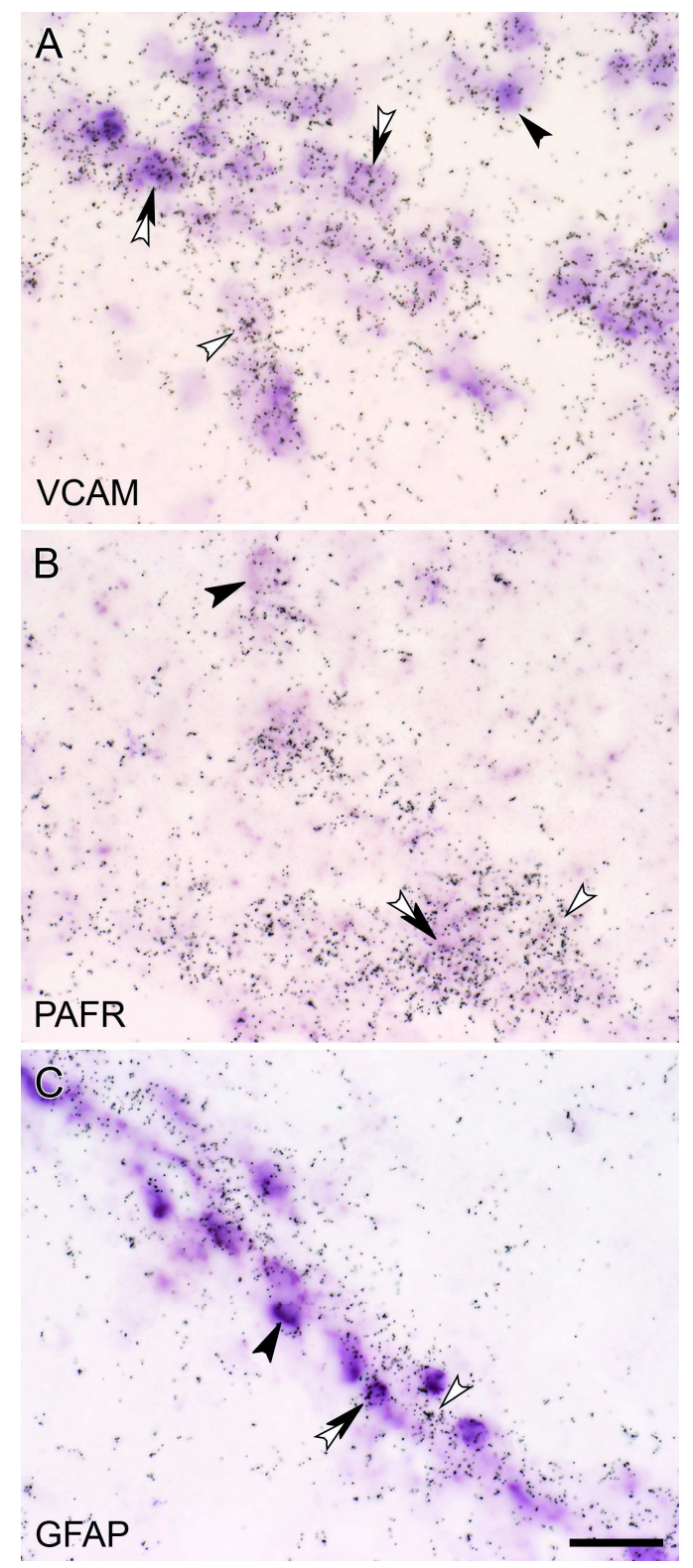

Figure 7. Characterization of cells displaying LPS-altered expression of PDE4B2. Cellular localization of PDE4B2 mRNA in activated endothelial, microglial and astrocytic cell populations in mouse leptomeninges $3 \mathrm{~h}$ post-injection. High-magnification bright-field microphotographs of emulsion dipped sections, simultaneously showing mRNA visualized by double in situ hybridization using ${ }^{33} \mathrm{P}$-labeled oligonucleotides complementary to the mRNA coding for PDE4B2 (clusters of dark silver grains), and DIG-labeled oligonucleotides (dark-purple precipitate) for (A) VCAM mRNA, endothelial cells, (B) PAFR mRNA, microglial/macrophage cells, or (C) GFAP mRNA, astrocytes. Black arrowheads point to digoxigenin-labeled cells, white arrowheads to radioactively-labeled cells and double white and black arrowheads to double-labeled cells. GFAP, glial fibrillary acidic protein; LPS, lipopolysaccharide; PAFR, platelet-activating factor receptor; PDE, phosphodiesterase; VCAM, vascular cell adhesion molecule. Bar $=20 \mu \mathrm{m}$. $82 \times 194 \mathrm{~mm}(480 \times 480$ DPI $)$ 


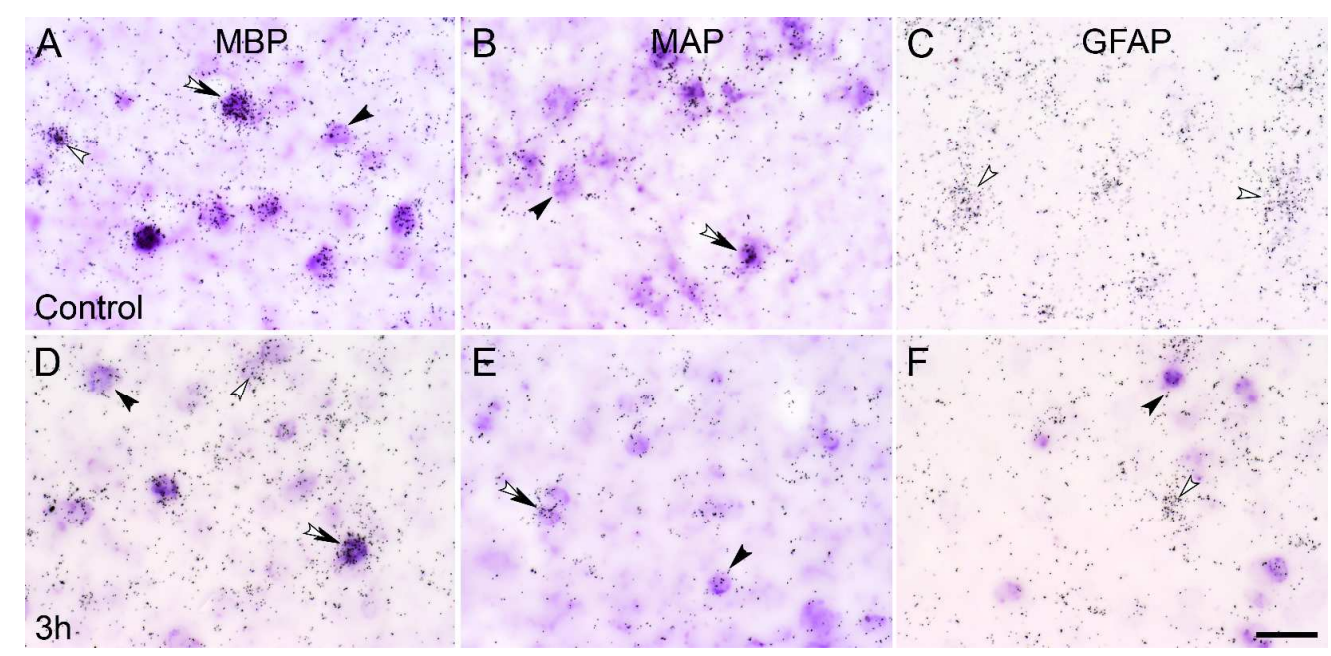

Figure 8. Characterization of cells displaying LPS-altered expression of PDE4B3. Cellular localization of PDE4B3 mRNA (cluster of dark silver grains) in, $(\mathbf{A}, \mathbf{D})$ oligodendrocytes, MBP mRNA positive cells; (B,E) neurons, MAP mRNA positive cells and $(\mathbf{C}, \mathbf{F})$ astrocytes, GFAP mRNA positive cells in mouse brain parenchyma (IC) in control and $3 \mathrm{~h}$ post-injection. Black arrowheads point to digoxigenin-labeled cells (dark-purple precipitate), white arrowheads to radioactively-labeled cells and double white and black arrowheads to double-labeled cells. Note the reduction in PDE4B3 mRNA after LPS injection (D,E,F). GFAP, glial fibrillary acidic protein; LPS, lipopolysaccharide; MAP, microtubule-associated protein; MBP, myelin basic protein; PDE, phosphodiesterase. Bar $=20 \mu \mathrm{m}$. $172 \times 83 \mathrm{~mm}(480 \times 480 \mathrm{DPI})$ 